\author{
С.С. Дроздов ${ }^{1}$, О.Б. Леонтьєв ${ }^{2}$, М.В. Науменко ${ }^{2}$
}

${ }^{1}$ Командування Повітряних Сил Збройних Сил Украӥни, Вінниия

${ }^{2}$ Харківський наџіональний університет Повітряних Сил ім. І. Кожедуба, Харків

\title{
ФОРМАЛІЗОВАНІ КРИТЕРІЇ РАЦІОНАЛЬНОСТІ ПРОГРАМИ РОЗВИТКУ СИСТЕМИ ОЗБРОЄННЯ ТАКТИЧНОЇ АВІАЦІЇ ПОВІТРЯНИХ СИЛ ЗБРОЙНИХ СИЛ УКРАЇНИ НА ДОВГОСТРОКОВІЙ ПЕРСПЕКТИВІ
}

Розглянуто основні можслві випадки нестачі бойової спроможності тактичної авіації Повітряних Сил Збройних Сил Украӥни на початку довгострокового періоду планування розвитку ї̈ системи озброєння та пов'язані з ними можливі варіанти обрання стратегій переоснащення авіаційних частин на нову бойову авіаційну техніку для ліквідації наявної нестачі. Названі варіанти стратегій пропонується звести у три основні групи, а саме стратегію сталого розвитку, коли необхідна спроможність досягається наприкінці періоду планування, стратегію постійної ліквідації нестачі спроможності вздовж всього періоду планування, та стратегію швидкої ліквідації нестачі спроможності за мінімально можливий час. Запропоновано формалізовані, із застосуванням методу бойових потенціалів, критерї ращіональності програми розвитку системи озброєння тактичної авіації Повітряних Сил Збройних Сил Украӥни, за допомогою використання яких, на відміну від відомих методичних підходів, можливо здійснити синтез такої раціональної програми у зворотній постановиі математичної задачі оптимізації.

Ключові слова: планування на основі спроможностей, критерії раціональності, науково-методичний апарат, оптимізація, раціональна програма розвитку, система озброєння тактичної авіації Повітряних Сил Збройних Сил Украӥни.

\section{Вступ}

Постановка проблеми. Сучасний стан системи озброєння тактичної авіації Повітряних Сил (ПС) Збройних Сил (ЗС) України потребує термінового вирішення проблеми оновлення парку бойових літаків. Окрім морального та фізичного зносу наявної бойової авіаційної техніки, актуальності названій прикладній проблемі надає зміна за часом оперативного середовища, в якому будуть функціонувати Збройні Сили України, в тому числі, тактична авіація ПС ЗС України, у середньо та довгостроковій перспективі. Такі зміни обумовлюють виникнення суттєвої нестачі спроможності тактичної авіації у вирішенні оперативних і бойових завдань вже у найближчому майбутньому та потребують урахування в процесі оборонного планування розвитку іiі системи озброєння.

В сучасних умовах трансформаційних перетворень в системі оборонного планування у Збройних Силах України реалізуються прийняті у країнахчленах НАТО підходи до планування на основі спроможностей, які грунтуються на концепції розвитку сил оборони країн-партнерів за принципом “ефективність на противагу кількості” та які здійснюють функціональну інтеграцію процесів оборонного і бюджетного планування. У цьому напрямку в Збройних Силах України зроблено рішучі кроки на шляху вдосконалення системи оборонного планування та здійснюється втілення нових підходів у прийнятті ключових нормативно-правових докумен- тів 3 організації оборонного планування [1-4]. Це стало каталізатором проведення науководослідними установами 3С України досліджень щодо приведення у відповідність існуючого науково-методичного апарату формування програм і планів розвитку системи озброєння та військової техніки, в першу чергу видів Збройних Сил України, сучасним вимогам, пошуку шляхів його подальшого удосконалення. Об'єктивна реальність диктує жорсткі вимоги щодо забезпечення досягнення необхідного рівня спроможності як ЗС України в цілому, так і видів (родів) військ. При цьому сам процес розвитку спроможності повинен бути збалансованим із економічною спроможністю держави, що вимагає потребу у формуванні раціональних програм розвитку озброєння та військової техніки. Це, у свою чергу, обумовлює актуальність проведення досліджень щодо формування формалізованих критеріїв раціональності варіантів побудови та програм розвитку системи озброєння, зокрема системи озброєння тактичної авіації Повітряних Сил Збройних Сил України.

Аналіз останніх досліджень і публікацій. В умовах сьогодення, коли мова йде про оборонне планування, загально прийнятним $€$ формування програм і планів розвитку системи озброєння, зокрема видів Збройних Сил України. При цьому, синтез програм розвитку здійснюється за схемою так званого прямого синтезу, коли здійснюється генерація обмеженої кількості альтернатив, послідовне їх оцінювання та обрання кращого варіанту за прийня- 
тою системою критеріїв, наприклад, роботи [4-9]. Такий підхід, окрім суттєвої обмеженості кількості варіантів, що розглядається як альтернативи, у зв'язку із великою розмірністю задачі вибору, потребує значних витрат сил та часу на пошук раціонального рішення. Доказової бази, що знайдене рішення є раціональним, взагалі створити не можливо, оскільки в наслідок обмеженої кількості альтернатив важко довести, що кращої не існує. До того ж, в такій спосіб вдається визначитися 3 кінцевою метою розвитку системи озброєння та складно визначитися із раціональністю самої програми розподілу кількісно-якісного складу (типажу та кількості) нової техніки, що потребує постачання у війська за часом на періоді планування з урахуванням зміни зовнішніх та внутрішніх чинників.

Альтернативним підходом $\epsilon$ постановка зворотної задачі оптимізації кількісно-якісного складу нової бойової авіаційної техніки в системі озброєння тактичної авіації, що викладено в ряді робіт [10-12]. Такий підхід дозволяє розглядати безліч альтернатив кількісного складу бойових літаків при визначеному їх альтернативному набору типажу, але і він дозволяє визначитися лише тільки із кінцевим раціональним кількісно-якісним складом наприкінці терміну планування та на сучасному рівні свого розвитку є непридатним для синтезу раціональної програми оновлення парку літаків тактичної авіації.

Решта сучасних досліджень [6; 13-17] в більшому ступені спрямовані на оцінку якості, релевантності та реалізуємості вже синтезованих в будьякий спосіб програм. Їх результати зводяться до аналізу стану виконання програм та планів розвитку системи озброєння та військової техніки (ОВТ) Збройних Сил України, виявляють наявність суттєвих відхилень фактично отриманих результатів виконання програм і планів від запланованих, та дозволяють розроблювати рекомендації щодо мінімізації негативного впливу наявних відхилень на загальний результат виконання заходів розвитку системи ОВТ.

В таких роботах акцент ставиться саме на критеріях оцінювання реалізації вже якимось чином сформованих програм, а дослідженню питання щодо розробки науково-методичного апарату щодо, власне, формування раціональних програм розвитку OВТ належної уваги не приділено. Зокрема, не $є$ достатньо дослідженими питання пошуку оптимального кількісно-якісного складу, зокрема тактичної авіації Повітряних Сил Збройних Сил України, та зміни його за часом, а також оцінюванню раціональності програм розвитку озброєння на етапі їх формування і можливого корегування із врахуванням фактору часу, під впливом якого можуть бути зміни, як в оперативному середовищі, так і у фінансуванні запланованих заходів.
Як показує проведений аналіз [6; 13-17], проблема переозброєння Збройних Сил України, що актуальна саме для авіації Повітряних Сил, з точки зору науково-методичного забезпечення розглядається у площині пошуку раціональних і економічно обгрунтованих шляхів їх оснащення сучасними зразками ОВТ як проведення комплексу наукових досліджень, щодо обгрунтування завдань і заходів середньострокових програм озброєння. Вирішення цього питання традиційно знаходиться в системі досліджень за критерієм “ефективність-вартість”, але при цьому системна ув'язка із фактором часу критеріїв, що пропонуються, відсутня.

За результатами проведених на сьогодні наукових досліджень у напрямку вдосконалення науковометодичного апарату щодо обгрунтування та прийняття рішень по вибору шляхів забезпечення Збройних Сил України сучасними зразками ОВТ на етапі формування середньострокових (довгострокових) програм озброєння, можна зробити висновок, що існуючі методичні підходи, як правило, обмежуються урахуванням принципу щодо мінімізації витрат держави на їх придбання, експлуатацію (бойове застосування) та утилізацію ОВТ, але досліджень щодо власне обгрунтування того самого необхідного рівня спроможностей, який має забезпечити майбутній кількісно-якісний склад авіаційних угруповань у середньостроковій та довгостроковій перспективі, вкрай недостатньо.

У переважній більшості наукових досліджень щодо аналізу впливу факторів на прогнозні показники необхідного рівня спроможностей угруповань розглядається одним із ключових аспектів можливість досягнення зразками ОВТ більшого значення коефіцієнту технічної досконалості. Але навіть виконання, за сприятливих умов, цього прагнення не завжди дає відповідь на запитання щодо впливу сукупності цих зразків ОВТ на бойовий потенціал угруповання, у якому ці зразки мають застосовуватися, тому науково-методичний апарат (НМА) врахування технічного рівня зразків ОВТ при формуванні варіантів програм розвитку системи озброєння потребує вдосконалення. Таке удосконалення передбачається у напрямку врахування бойових спроможностей зразків ОВТ та їх впливу на бойові спроможності угруповання, у складі якого планується їх залучати для виконання завдань за всіма визначеними сценаріями застосування Повітряних Сил Збройних Сил України. Це має бути складовою частиною критеріїв оцінювання варіантів побудови та синтезу програм розвитку системи озброєння тактичної авіації Повітряних Сил Збройних Сил України.

При формуванні програм і планів розвитку озброєння неминучим є дослідження питання щодо потенційних можливостей оборонних підприємств виробництва оборонної продукції у визначені 
контрактами терміни на середньостроковій (довгостроковій) перспективі. Слід відмітити, що такі дослідження мають бути проведені як для обороннопромислового комплексу (ОПК) України, так і для військової промисловості потенційного противника. Нажаль, в Україні на теперішній час вітчизняні підприємства ОПК спроможні виробляти за замкненим циклом менше $10 \%$ загальної номенклатури ОВТ для потреб Збройних Сил України [17]. Виробництво літаків тактичної авіації не входить у ці відсотки. Ще більш актуальним вирішення цього питання робить світовий досвід, який свідчить, що для підтримання 3С у боєздатному стані необхідно щорічно оновлювати 4-6\% парку бойової техніки [18].

3 урахуванням апріорної неможливості задоволення потреб Збройних Сил України у тактичній авіації за рахунок вітчизняного ОПК та, за сукупності причин, неможливості розгортання власного виробництва літаків тактичної авіації, актуалізується питання вдосконалення науково-методичного апарату щодо формування шляхів оснащення Повітряних Сил в рамках військово-технічного співробітництва 3 іноземними країнами. Цей аспект також має бути складовою частиною критеріїв оптимальності формування програм та планів розвитку системи озброєння тактичної авіації Повітряних Сил Збройних Сил України [19-20].

Актуальність формування коректних критеріїв для оцінювання програм розвитку системи ОВТ Повітряних Сил Збройних Сил України на етапі їх формування та формалізації таких критеріїв підсилюється терміновістю вирішення питання щодо шляхів переозброєння тактичної авіації Повітряних Сил Збройних Сил України, що відображено у представленій в травні 2020 року Візії Повітряних Сил 2035 [24].

3 оглядом на результати наведеного вище аналізу стану питання метою статті $є$ формування формалізованих критеріїв раціональності програми розвитку системи озброєння авіації ПС ЗС України на довгостроковій перспективі, які би дозволяли здійснювати постановку та розв'язування задачі синтезу такої програми у вигляді зворотної математичної задачі оптимізації.

\section{Виклад основного матеріалу}

Одним із ключових етапів реалізації оборонного планування розвитку Збройних Сил та їх складових, згідно Рекомендацій $з$ оборонного планування на основі спроможностей [4], є формування перспективного обрису складових Сил оборони, що передбачає розроблення варіантів кількісно-якісного їх складу взагалі, зокрема тактичної авіації ПС ЗС України, формування раціонального співвідношення різних типів озброєння (систем озброєння) для виконання оперативних (оперативно-тактичних) задач видом Збройних Сил України на середньостроковій (довгостроковій) перспективі та синтез раціональної програми досягнення визначеного перспективного обрису на основі критерію “результатвартість-час" з урахуванням наявних обмежень.

Оскільки задача обгрунтування раціональної програми розвитку системи озброєння є системною, яка має вирішуватися із врахуванням багатьох факторів різної природи (як внутрішніх так і зовнішніх), які можуть вплинути як на показники самої програми, так і на можливість успішної їі реалізації, необхідним є грунтовно підійти до питання обгрунтування множини значущих факторів, які мають бути враховані при формуванні формалізованих критеріїв оцінювання раціональності програми розвитку системи озброєння тактичної авіації ПС ЗС України на етапі їі синтезу.

Згідно вимог керівних документів [4], початком оборонного планування має стати оцінювання середовища безпеки та формування вимог до спроможностей складових Збройних Сил України, а також оцінка наявних спроможностей щодо виконання завдань за всіма визначеними сценаріями ймовірного застосування, зокрема, Повітряних Сил Збройних Сил України.

За результатами оцінювання середовища безпеки мають бути отримані вихідні дані для наступних етапів формування програм розвитку системи озброєння, а саме:

- проведено оцінювання перспективи розвитку воєнно-політичної (воєнно-стратегічної) обстановки навколо України на довгострокову перспективу;

- визначений перелік викликів та загроз, що мають нівелювати ПС ЗС України;

- сформовані на їх основі ймовірні сценарії розвитку кризових ситуацій та варіанти застосування за кожним сценарієм застосування тактичної авіації Повітряних Сил Збройних Сил України.

Якщо оцінювання середовища безпеки - це в більшому ступені прерогатива Міністерства оборони України та Генерального штабу Збройних Сил України, то розробка програмних документів розвитку спроможностей видів Збройних Сил України і їх складових, а також організація роботи в підпорядкованих структурах щодо виконання заходів середньострокового (довгострокового) оборонного планування покладається на командування видів Збройних Сил України, а наукове супроводження названих процесів - на підпорядковані науково-дослідні установи [4]. Для пошуку шляхів досягнення Повітряними Силами Збройних Сил України необхідного рівня спроможностей за всіма визначеними сценаріями їх застосування відправною межею має стати співвідношення рівнів потрібних та наявних спроможностей тактичної авіації ПС ЗС України за ймовірними сценаріями їх застосування, а також необ- 
хідний час набуття потрібного рівня спроможностей.

Одним із основних елементів, який по завершенню оцінювання середовища безпеки має отримати кількісну оцінку із можливістю його подальшого врахування при формуванні програм і планів розвитку системи озброєння тактичної авіації Повітряних Сил, є оцінка воєнно-економічного (бойового) потенціалу повітряно-ударної компоненти ймовірного противника (кількісно-якісний склад авіаційних угруповань) та прогноз його зміни у часі. Цей результат у подальшому буде обумовлювати необхідний рівень спроможності тактичної авіації ПС Збройних Сил України для забезпечення виконання покладених завдань за визначеними сценаріями застосування, а також необхідні його зміни у часі на програмному періоді.

Оцінювання прогнозу зміни кількісно-якісного стану авіаційної компоненти потенційного противника має спиратися на результати аналізу економічної спроможності держави-агресора, оскільки обсяги фінансових ресурсів, що будуть заплановані на оборонні витрати потенційного противника, будуть обумовлювати результативність та оперативність функціонування його оборонної промисловості. Це буде підгрунтям для прогнозування можливих темпів розробок, і серійного виробництва новітніх зразків ОВТ, що можуть бути застосовані у складі повітряної компоненти потенційного противника у певний момент часу, та будуть визначати ймовірні форми та способи їі застосування.

Результатом оцінювання середовища безпеки, 3 одного боку, і вихідними даними для подальшого планування, 3 другого боку, має бути отримання оцінки ймовірності виникнення кризових ситуації, особливості умов імовірного конфлікту та визначення сценаріїв застосування тактичної авіації Повітряних Сил Збройних Сил України. Звідси витікають грунтовні вимоги до спроможностей тактичної авіації перспективних ПС ЗС України щодо виконання завдань за всіма сценаріями на всій глибині планування.

Оцінювання рівня потрібних та наявних спроможностей тактичної авіації ПС Збройних Сил України пропонується проводити на основі потенційно-пайового методу (методу бойових потенціалів) оцінювання бойових можливостей військ, як найбільш придатного для формалізації критеріїв оптимальності програм розвитку системи озброєння $[10 ; 21]$. При цьому, необхідний рівень бойового потенціалу угруповань тактичної авіації ПС ЗС України буде поставлено у відповідність бойовому потенціалу авіаційних угруповань ймовірного противника у виконанні відповідних задач у його складі, які обумовлюватимуть форми і способи застосування тактичної авіцції Повітряних Сил ЗС України (що повинно бути відображено у визначеному для
Повітряних Сил переліку спроможностей), наприклад [23]. Ключовою позицією формування відповідності наявного рівня спроможностей тактичної авіації ПС Збройних Сил України рівню бойового потенціалу ймовірного противника у реалізації ним своїх бойових завдань $є$ врахування можливих змін у кількісно-якісному складі авіаційних частин противника. Це буде обумовлювати зміну у часі бойового потенціалу авіаційних угруповань ймовірного противника та вносити корективи до вимог досягнення необхідного рівня спроможностей (або термінів досягнення необхідного рівня спроможностей) тактичної авіації Повітряних Сил Збройних Сил України.

Формалізовано відповідність зміни за часом потрібного рівня бойового потенціалу угруповань тактичної авіації Повітряних Сил Збройних Сил України для виконання покладеного на нього $i$-го типу завдання за визначеними сценаріями застосування може бути оцінена за наступним виразом [10]:

$$
P_{\text {необх } i}(t)=f_{i}\left(\sum_{j=1}^{s} K_{\text {БП } i j}^{n p} N_{i j}^{n p}(t)\right),
$$

де $N_{i j}^{n p}(t)$ - зміна за часом нарядів сил та засобів $j$-го типу потенційного противника, що складатимуть об'єкти дії тактичної авіації ПС ЗС України при виконанні нею $i$-го завдання;

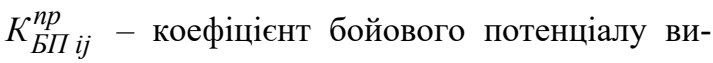
значених бойових засобів противника $j$-го типу у виконанні ним завдань для умов $i$-го завдання тактичної авіації ПС ЗС України.

Оцінювання зміни за часом співвідношення необхідного рівня бойового потенціалу тактичної авіації ПС ЗС України та бойового потенціалу авіаційних угруповань ймовірного противника може здійснюватися за будь-якими іншими методами оцінювання бойових можливостей військ (сил), ніж потенційно-пайовий, наприклад, на основі використання відомих аналітичних алгоритмів теорії дослідження операцій, зокрема теорії бойової ефективності авіаційних комплексів, або алгоритмами різноманітних імітаційних моделюючих комплексів. Важливим тут $\epsilon$ визначення саме потрібного співвідношення бойових потенціалів тактичної авіації та сил противника, достатніх, при умові можливості реалізації, для досягнення потрібного рівня виконання покладеного бойового завдання (наприклад, для нанесення нормованого рівня збитку противнику).

Складова критеріїв раціональності програми розвитку системи озброєння авіації Повітряних Сил 3С України, що описує зміну у часі на інтервалі $[0, \ldots t]$ наявного бойового потенціалу угруповань тактичної авіації ПС ЗС України для виконання $i$-го 
бойового завдання $(i=\overline{1 . . . m})$ за рахунок накопичення нових зразків авіаційної техніки, та виводу із експлуатації тих літальних апаратів, що вичерпали експлуатаційний ресурс (або прийняте рішення про недоцільність їх експлуатаціі), у формалізованому вигляді може бути представлена наступним чином [21]:

$$
P_{\text {наяв } i}(t)=\int_{t_{0}}^{t} \sum_{j=1}^{n} K_{\text {БПij }} \sum_{r=1}^{m} \delta_{i j r} \dot{N}_{j r}(t) d t,
$$

де $n$ - кількість типів літальних апаратів, що входять до складу авіаційного угруповання ПС Збройних Сил України;

$m$ - кількість бойових завдань із сукупності завдань, що визначені до виконання авіаційним угрупованням по всіх можливих сценаріях застосування тактичної авіації Повітряних Сил ЗС України;

$K_{\text {БПіј }}$ - значення коефіцієнту бойового потенціалу у вирішенні $i$-го завдання зразком $j$-го типу;

$\delta_{i j r}$ - символ, який характеризує можливість залучення засобів $j$-го типу до виконання $i$-го бойового завдання та інших бойових завдань з сукупності $m$ завдань водночас у відповідності до визначеної структури бойового потенціалу авіаційного угруповання $\left(\delta_{i j r}=1-\right.$ при можливості одним й тим же засобом $j$-го типу виконувати бойове завдання $i$-го типу водночас 3 завданням $r$-го типу, та $\delta_{i j r}=0$ - при неможливості цього);

$P_{\text {наяв } i}(t)$ - частка наявного бойового потенціалу авіаційного угруповання, що здатна бути реалізованою при виконанні $i$-го бойового завдання у кожний момент часу $t$ на всій глибині прогнозування;

$\dot{N}_{j r}(t)$ - похідна залежності зміни кількості бойових літаків $j$-го типу за часом, що можуть бути залученими до виконання $r$-го бойового завдання $3 m$ покладених, яка обумовлена виведенням літаків даного типу з бойового складу авіації ПС 3С України за різними чинниками (вичерпання призначених технічного ресурсу або строку служби, прийняттям рішення щодо недоцільності використання тощо).

За результатами оцінювання відповідності наявних спроможностей необхідним (потрібним) для кожного з визначених сценаріїв та по кожному завданню в його межах, в узагальненому вигляді можуть бути наступні варіанти результатів оцінювання стану тактичної авіації ПС ЗС України на початку терміну планування [21]:

- наявні спроможності $P_{\text {наяв } i}\left(t_{0}\right)$ незначною мірою відрізняються від необхідних $P_{\text {необх } i}\left(t_{0}\right)$ та можуть вважатися відповідними й такими, в розвитку яких немає потреби, або потреба в їх розвитку може виникнути через деякий проміжок часу $\left(\Delta P_{i}\left(t_{0}\right)=P_{\text {необх } і}\left(t_{0}\right)-P_{\text {наяв } i}\left(t_{0}\right) \approx 0\right)$;

- наявні спроможності суттєво поступаються необхідним, є критичними та потребують негайного розвитку $\left(\Delta P_{i}\left(t_{0}\right)>0\right)$;

- наявні спроможності суттєво перевищують необхідні та потребують або зменшення або ліквідації $\left(\Delta P_{i}\left(t_{0}\right)<0\right)$.

В залежності від співвідношення наявних і потрібних спроможностей на початку періоду планування мають бути сплановані програмні заходи щодо усунення дисбалансу між наявними та потрібними спроможностями тактичної авіації ПС ЗС України. Вибір стратегії розвитку системи озброєння авіації та формування відповідних програм буде обумовлюватися метою та задачами, виконання яких буде покладено на Повітряні Сили, тому, вочевидь, критерії оцінювання раціональності програми розвитку системи озброєння, що синтезується, за кожною стратегією розвитку системи озброєння тактичної авіації ПС Збройних Сил України будуть різними. Розглянемо можливі варіанти критеріїв оцінювання програм розвитку системи озброєння авіації в залежності від обраної стратегії іiі розвитку.

У першому випадку, коли наявні спроможності незначною мірою відрізняються від необхідних, та за результатами оцінювання зміни середовища безпеки не очікується значного збільшення бойового потенціалу авіаційних угруповань імовірного противника та немає передумов для принципової зміни форм та способів ведення повітряних операцій, мова може йти про планомірний розвиток (підтримання на необхідному рівні) наявних спроможностей для виконання завдань за визначеними сценаріями застосування ПС ЗС України і досягнення необхідного рівня спроможностей наприкінці терміну планування (стратегія сталого розвитку).

У такому разі в якості цільової функції критерію раціональності програми розвитку системи озброєння авіації, що синтезується, доцільно обрати показник сумарних витрат коштів Державного бюджету України на закупівлю літаків, відповідної авіаційної зброї, забезпечення належної інфраструктури, для якісної експлуатації нових літальних апаратів, а також витрати на освоєння нової техніки льотним та інженерним складом авіаційних частин на всьому визначеному терміні планування, тобто від початку реалізації заходів $\left(t_{0}\right)$ до їх завершення $\left(T_{\text {зад }}\right)$.

Для оцінювання вартісної складової цільової функції, що пропонується, доцільно використовува- 
ти методи функціонально-вартісного аналізу. Одним 3 варіантів таких методів є той, що заснований на побудові та використанні математичної моделі вартості серійного зразка, яка встановлює зв'язок між вартістю серійного екземпляру зі значеннями або узагальнених показників якості зразка, або зі значеннями визначаючих бойові властивості зразка тактико-технічними характеристиками $[10 ; 21]$.

У формалізованому вигляді цільова функція критерію раціональності програми розвитку системи озброєння авіації за стратегією сталого розвитку може бути представлена як:

$$
S=\int_{t_{0}}^{T_{3 a}} \sum_{j=1}^{n} C_{1 j} \sum_{r=1}^{m} \dot{X}_{j r}(t) d t \rightarrow \min ,
$$

де $\left[t_{0}, T_{\text {зад }}\right]$ - інтервал часу, на який здійснюється синтез програми розвитку системи озброєння авіації ПС ЗС України;

$$
\dot{X}_{j r}(t) \text { - похідна за часом функції кількості лі- }
$$
таків $j$-го типу, що використовуються для набуття $r$-ї спроможності, яких треба поставити у війська (темп оновлення парку за рахунок літаків даного типу);

$C_{1 j}$ - вартість закупівлі одного серійного зразка літаків $j$-го типу.

Окрім обгрунтування і формалізації цільової функції критерію раціональності програми розвитку системи озброєння авіації Повітряних Сил Збройних Сил України за стратегією сталого розвитку, об'єктивно мають бути визначені певні обмеження щодо синтезу програми. Перш за все, це забезпечення необхідного рівня виконання завдань за визначеними сценаріями застосування ПС ЗС України на всьому плановому періоді, тобто забезпечення такого рівня бойового потенціалу авіації Повітряних Сил у виконанні завдань за визначеними сценаріями застосування, який би гарантував на всьому інтерва-

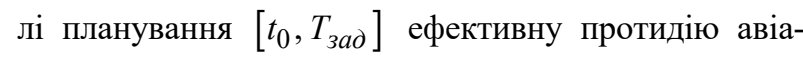
ційним угрупованням ймовірного противника з урахуванням можливих змін у часі бойового потенціалу авіаційної компоненти ймовірного противника, що може бути обумовлено зміною кількісно-якісного складу його авіаційних угруповань. Формалізація такого обмеження наведена нижче:

$$
\int_{t_{0}}^{T_{\text {зад }}} \sum_{j=1}^{n} K_{\text {БПij }} \sum_{r=1}^{m} \delta_{i j r} \dot{X}_{r j}(t) d t \geq \Delta P_{i}\left(T_{3 a \partial}\right) .
$$

Окрім обмеження щодо нарощення спроможності за рахунок зміни рівня бойового потенціалу тактичної авіації Повітряних Сил Збройних Сил України у виконанні $i$-го бойового завдання $(i=\overline{1 \ldots m})$, необхідною $\epsilon$ вимога щодо реалізації заходів, що плануються, у визначені терміни, тобто до заданого моменту часу:

$$
T_{\text {гот } i} \leq T_{\text {зад }} .
$$

Для оцінювання часу набуття тактичною авіацією необхідного рівня спроможності у виконанні $i$-го бойового завдання доцільно використовувати спеціальні методи, що враховуватимуть вплив таких факторів, як терміни підписання контрактів щодо поставок авіаційної техніки, терміни виробництва (модернізації) літаків іноземного виробництва, терміни формування відповідної інфраструктури та витрати часу на навчання і підготовку персоналу. Також ключовим фактором $є$ своєчасність фінансування реалізації заходів, що плануються.

Таким чином, узагальнюючи наведене вище обгрунтування цільової функції, основних обмежень, які мають бути враховані при синтезі програми розвитку спроможності тактичної авіації ПС Збройних Сил України, формалізований критерій оцінювання раціональності програми розвитку системи озброєння авіації за умови планомірного нарощування спроможностей на визначеній глибині планування буде мати загальний вигляд:

$$
\left\{\begin{array}{l}
\int_{t_{0}}^{T_{\text {зад }}} \sum_{j=1}^{n} K_{\text {БПij }} \sum_{r=1}^{m} \delta_{i j r} \dot{X}_{r j}(t) d t \geq \Delta P_{i}\left(T_{\text {зад }}\right), \forall i=\overline{1, m} ; \\
S=\int_{t_{0}}^{T_{3 a \partial}} \sum_{j=1}^{n} C_{1 j} \sum_{r=1}^{m} \dot{X}_{r j}(t) d t \rightarrow \min , \forall j=\overline{1, n} ; \\
T_{\text {гот } i} \leq T_{\text {зад }} ; \\
\sum_{j=1}^{n} \sum_{r=1}^{m} X_{r j} \leq X_{\max } \\
X_{j}=\sum_{r=1}^{m} X_{r j} \leq X_{j \max }
\end{array}\right.
$$

де $X_{\max }, X_{j \max }$ - обмеження, що можуть бути накладені на загальну кількість літаків в складі парку авіаційної техніки тактичної авіації, або літаків $j$-го типу.

У графічному вигляді синтез програми розвитку системи озброєння авіації Повітряних Сил за стратегією сталого розвитку наведено на рис. 1.

Таким чином, раціональною програмою розвитку системи озброєння авіації за вибором стратегії сталого розвитку буде вважатися та програма, яка передбачає поступове нарощування спроможностей угруповань авіації Повітряних Сил Збройних Сил України і доведення їх наявних спроможностей у виконанні завдань за визначеними сценаріями до необхідного рівня не пізніше заданого строку $T_{\text {зад }}$, та на реалізацію якої знадобиться найменший фінансовий ресурс на всій глибині планування. 


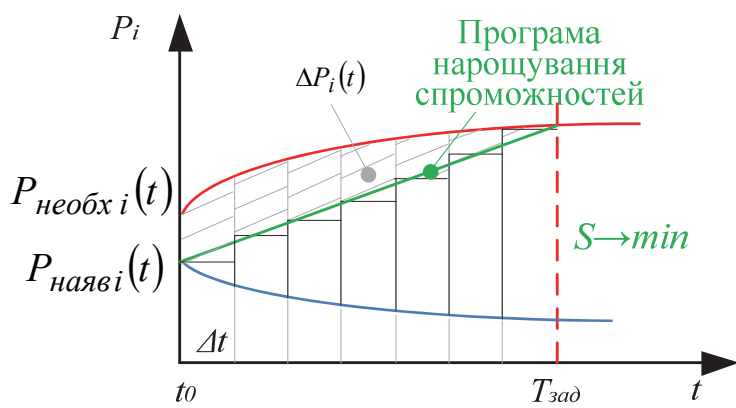

Рис. 1. Синтез програми планомірного нарощування рівня спроможностей

У другому випадку, коли наявні спроможності за задачами у визначених сценаріях застосування суттєво поступаються необхідним, є критичними та потребують негайного розвитку, доцільно розглядати шляхи якомога швидкого переозброєння авіаційних частин і гарантованого доведення наявних спроможностей угруповань тактичної авіації у виконанні завдань за визначеними сценаріями до необхідного рівня за умови фінансових витрат не більше можливих (заданих) обсягів. Така ситуація може скластися за умови несприятливого прогнозу розвитку середовища безпеки, інтенсивного нарощування бойового потенціалу авіаційних угруповань імовірного противника, нарощування темпів виробництва та постачання у війська новітніх зразків ОВТ, які можуть бути застосовані у авіаційній компоненті потенційного противника, прискорення темпів навчання льотного та інженерного складу щодо освоєння новітніх літаків, збільшення прогнозованого фінансування повітряних сил потенційного противника, або, у найгіршому випадку, швидкої вимушеної мобілізації країни для відсічи несподіваної агресії.

У цьому випадку, в умовах майже досягнутого граничного терміну експлуатації наявного авіаційного парку тактичної авіації Повітряних Сил ЗС України, можуть розглядатися усі можливі варіанти його термінового (невідкладного) переозброєння. Це може бути швидка закупівля літаків, або придбання техніки у лізинг у можливих закордонних постачальників. Надкритичними питаннями на цьому шляху буде фінансова можливість забезпечення таких варіантів оновлення тактичної авіації та наявність на світовому ринку літаків, 3 відповідними льотнотехнічними характеристиками, які буде можливим закупити та які мають забезпечити набуття тактичною авіацією ПС ЗС України необхідних спроможностей для виконання завдань за визначеними сценаріями їх застосування в найкоротший час. Нажаль, цілком очевидно, що Державний бюджет України не має настільки значних резервів для оновлення парку тактичної авіації (за оцінками Командування ПС
Збройних Сил України мова може йти про 200 млрд. грн. [24]), тому для реалізації переозброєння авіаційного парку тактичної авіації у вимушено стислі терміни, варіантами вирішення цього питання може бути або фінансування (кредитування) програм переозброєння тактичної авіації в рамках партнерських домовленостей с країнами-членами НАТО, або закупівля більшої кількості літаків, льотнотехнічні характеристики яких в меншому ступені відповідають вимогам щодо забезпечення досягнення необхідного рівня спроможностей ПС ЗС України та можуть суттєво відхилятися від економічної раціональності.

Але слід зауважити, що для реалізації такої стратегії швидкої ліквідації нестачі спроможності за мінімально можливий час вимагаються значні обсяги фінансових витрат на початковому етапі переозброєння. В майбутньому, на наступних етапах переозброєння, слід очікувати, що подальші витрати будуть відносно невеликими у зв'язку із відносно невеликими вимогами до ступеня подальшого нарощування наявної спроможності угруповань тактичної авіації Повітряних Сил Збройних Сил до необхідного рівня.

При аналізі програми розвитку системи озброєння тактичної авіації за стратегію швидкої ліквідації нестачі спроможності за мінімально можливий час, акцент робиться на те, що для набуття необхідного рівня спроможностей за різними завданнями буде потрібний різний час.

У такому разі цільовою функцією критерію оцінювання раціональності програми розвитку швидкої ліквідації нестачі спроможності за мінімально можливий час, що синтезується, має стати досягнення найкоротшого терміну набуття спроможностей за всіма задачами у відповідних сценаріях застосування Повітряних Сил ЗС України. Формалізовано цільову функцію критерію раціональності програми розвитку за зазначеною стратегією можна записати у наступній формі:

$$
T_{\text {гот } i}(t)=\max _{i}\left(t_{i}\right) \rightarrow \min ,
$$

де $T_{\text {гот } i}(t)$ - час набуття необхідного рівня спроможності тактичною авіацією ПС ЗС у виконанні $i$-го бойового завдання.

Фізичний смисл цільової функції (7) полягає у мінімізації максимального часу набуття необхідного рівня спроможностей $\max \left(t_{i}\right)$ за всіма завданнями.

Разом із обгрунтуванням цільової функції критерію оптимальності програми термінового нарощування спроможностей Повітряних Сил, мають бути враховані обмеження щодо нарощування бойового потенціалу тактичної авіації та фінансової складової, 
що має забезпечити виконання програми переозброєння тактичної авіації ПС Збройних Сил України.

Обмеження щодо забезпечення нарощування спроможностей за кожним покладеним завданням у кожному визначеному сценарії формалізовано може бути представленим наступним чином:

$$
\int_{t_{0}}^{t_{i}} \sum_{j=1}^{n} K_{\text {БПij }} \sum_{r=1}^{m} \delta_{i j r} \dot{X}_{r j}(t) d t \geq \Delta P_{i}(t),
$$

де $t_{0}$ - початок терміну планування;

$t_{i}$ - час набуття необхідного рівня спроможностей тактичною авіацією ПС ЗС України для забезпечення виконання $i$-го бойового завдання.

Фізичний смисл обмеження (8) полягає у забезпеченні необхідного рівня бойового потенціалу угруповань тактичної авіації ПС ЗС України на інтервалі часу, що необхідний для досягнення відповідного рівня спроможностей за всіма бойовими завданнями.

Як відмічалося, для стратегії швидкої ліквідації нестачі спроможності за мінімально можливий час саме фінансова складова $є$ найбільш важливою, що буде обумовлювати взагалі можливість реалізації програми розвитку системи озброєння тактичної авіації ПС Збройних Сил України.

Фінансові обмеження щодо реалізації такої стратегії нарощування спроможностей можна формалізувати наступним виразом:

$$
S=\int_{t_{0}}^{\max _{i}} \sum_{j=1}^{t_{i}} C_{1 j} \sum_{r=1}^{m} \dot{X}_{r j}(t) d t \leq S_{3 а \partial}\left(\begin{array}{c}
\max t_{i} \\
i
\end{array}\right),
$$

де $\max t_{i}-$ найбільший час, $з$ усіх потрібних для набуття спроможності по всіх $m$ визначених бойових завданнях за всіма сценаріями і ситуаціями застосування тактичної авіації;

$$
S_{\text {зад }}\left(\begin{array}{c}
\max t_{i} \\
i
\end{array}\right) \text { - обсяг фінансового ресурсу, що }
$$

може бути виділений для нарощення спроможності до необхідного рівня, що описуються виразом

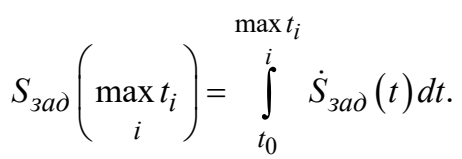

Доречно зауважити, що в деяких практичних випадках обмеження на ресурси можуть й не накладатися.

Таким чином, узагальнюючи наведене вище обгрунтування обрання цільової функції, необхідних обмежень, які мають бути враховані при синтезі програми термінового нарощування спроможностей тактичної авіації ПС ЗС України, формалізований критерій оцінювання раціональності програми розвитку системи озброєння авіації за стратегією швидкої ліквідації нестачі спроможності за мінімально можливий час буде мати загальний вигляд:

$$
\left\{\begin{array}{l}
\int_{t_{0}}^{t_{i}} \sum_{j=1}^{n} K_{\text {БПij }} \sum_{r=1}^{m} \delta_{i j r} \dot{X}_{r j}(t) d t \geq \Delta P_{i}(t), \forall i=1, m \\
\quad \max _{t_{i}}=\int_{t_{0}}^{i} \sum_{j=1}^{n} C_{1 j} \sum_{r=1}^{m} \dot{X}_{r j}(t) d t \leq S_{\text {зад }}\left(\begin{array}{c}
\max t_{i} \\
i
\end{array}\right) \\
T_{\text {гот } i}(t)=\max _{i}\left(t_{i}\right) \rightarrow \min \\
\sum_{j=1}^{n} \sum_{r=1}^{m} X_{r j} \leq X_{\max } \\
X_{j}=\sum_{r=1}^{m} X_{r j} \leq X_{j \max } .
\end{array}\right.
$$

У графічному вигляді синтез програми швидкої ліквідації нестачі спроможності за мінімально можливий час наведено на рис. 2.

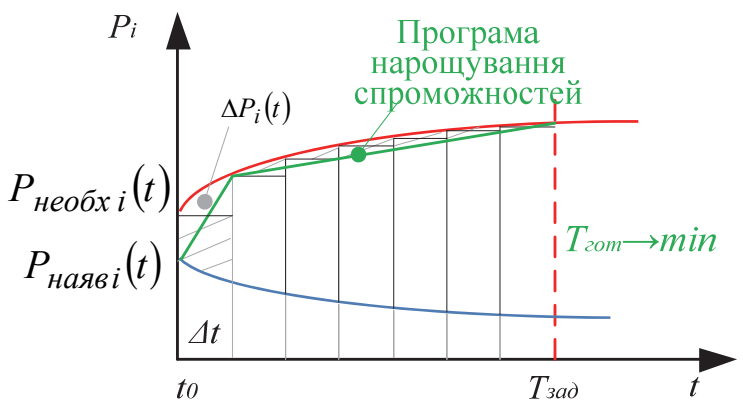

Рис. 2. Синтез програми “термінового” нарощування рівня спроможностей

Таким чином, раціональною програмою вимушено термінового оновлення парку бойової авіаційної техніки та нарощення спроможності тактичної авіації буде варіант програми, обраний за критерієм найкоротшого терміну досяжності необхідного рівня всіх без виключення спроможностей у визначених сценаріях застосування тактичної авіації ПС ЗС України при загальних витратах ресурсів, не більш ніж задані, або без накладання ресурсних обмежень (наприклад, швидка вимушена мобілізація країни для відсічи несподіваної агресіі).

Розглянемо варіант стратегії переозброєння авіаційних частин, який може мати місце у разі неможливості реалізації розглянутих вище - стратегію постійної ліквідації нестачі спроможності вздовж всього періоду планування 3 недосягненням необхідного рівня спроможності.

Така ситуація може скластися у випадку неможливості забезпечення висунутих раніше обмежень 
(4), (5), (8), (9) для реалізації стратегій сталого розвитку та швидкої ліквідації нестачі спроможності за мінімально можливий час.

Найбільш критичним для реалізації програми переозброєння тактичної авіації може стати неможливість фінансового забезпечення досягнення необхідного рівня спроможностей для виконання всього спектру завдань за визначеними сценаріями застосування ПС ЗС України на заданій глибині планування переозброєння тактичної авіації. Наслідком відсутності відповідного фінансування стане незабезпечення виконання термінів набуття заданого рівня спроможностей ПС Збройних Сил України.

За таких умов можливим шляхом підтримання боєздатності тактичної авіації ПС ЗС може стати той, за якого при обмеженому обсязі фінансування на заданому інтервалі планування може бути досягнуто найбільш можливого рівня нарощування всіх спроможностей тактичної авіації Повітряних Сил Збройних Сил України, або той варіант, який забезпечить необхідний рівень виконання максимальної кількості завдань за пріоритетними сценаріями застосування ПС Збройних Сил України.

Цільовою функцією критерію оцінювання такого варіанту розвитку спроможностей доцільно обрати наступну:

$$
\int_{t_{0}}^{t} \sum_{j=1}^{n} K_{\text {БПij }} \sum_{r=1}^{m} \delta_{i j r} \dot{X}_{j r}(t) d t \rightarrow \max .
$$

Відповідно до такого сценарію розвитку спроможностей, формалізація обмежень щодо фінансового ресурсу (12) та часу набуття (13) необхідного рівня спроможностей за визначеними пріоритетними завданнями пропонується оцінювати наступним чином:

$$
\begin{gathered}
\int_{t_{0}}^{t} \sum_{j=1}^{n} C_{1 j} \sum_{r=1}^{m} \dot{X}_{r j}(t) d t \leq S_{3 а д}(t) . \\
T_{\text {гот } i} \leq T_{\text {зад }},
\end{gathered}
$$

де $T_{\text {готі }}$ - час набуття необхідного рівня спроможностей за визначеними пріоритетними завданнями.

Таким чином, узагальнюючи обгрунтування вибору цільової функції, необхідних обмежень, які мають бути враховані при синтезі програми розвитку системи озброєння забезпечення необхідного рівня спроможностей за якомога більшої кількості завдань, що покладатимуться на авіацію ПС Збройних Сил України, формалізований критерій оцінювання раціональності програми розвитку системи озбросння авіації за стратегію постійної ліквідації нестачі спроможності вздовж всього періоду планування буде мати загальний вигляд:

$$
\left\{\begin{array}{l}
\int_{t_{0}}^{t} \sum_{j=1}^{n} K_{\text {БПij }} \sum_{r=1}^{m} \delta_{i j r} \dot{X}_{j r}(t) d t \rightarrow \max , \forall i=\overline{1, m} ; \\
\int_{t_{0}}^{t} \sum_{j=1}^{n} C_{1 j} \sum_{r=1}^{m} \dot{X}_{r j}(t) d t \leq S_{3 a \partial}(t), \forall j=\overline{1, n} ; \\
T_{20 m i} \leq T_{\text {зад }} ; \\
X_{j}=\sum_{r=1}^{m} X_{r j} \leq X_{j \max } \\
\sum_{j=1}^{n} \sum_{r=1}^{m} X_{r j} \leq X_{\max } .
\end{array}\right.
$$

У графічному вигляді синтез програми за критерієм максимальної реалізації обмежених ресурсів наведено на рис. 3.

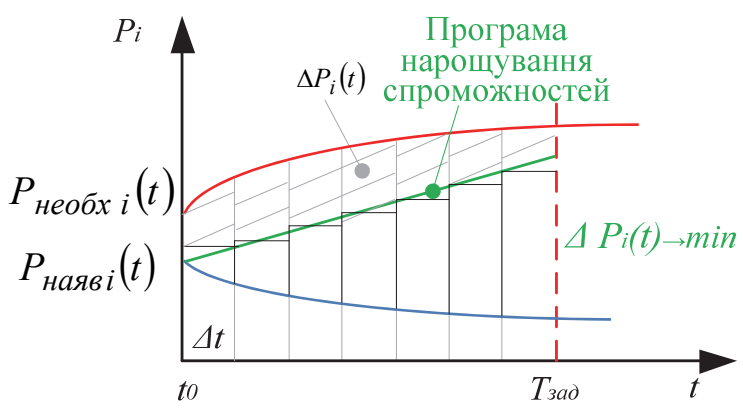

Рис. 3. Синтез програми нарощування рівня спроможностей за критерієм максимальної реалізації обмежених ресурсів

Таким чином, раціональною програмою розвитку спроможностей тактичної авіації ПС ЗС України за умови відсутності необхідних обсягів фінансування в задані терміни набуття заданого рівня спроможностей, доцільно обрати такий варіант програми, який забезпечить при обмеженому обсязі фінансування на заданому інтервалі планування найбільш можливого рівня нарощування всіх спроможностей угруповань авіації Повітряних Сил Збройних Сил України.

\section{Висновки}

Розроблено систему формалізованих критеріїв раціональності програм оновлення парку літальних апаратів тактичної авіації ПС ЗС України на довгостроковій перспективі типу “ефективність - вартість - час", які грунтуються на використанні методу бойових потенціалів та враховують зміни за часом кількісних показників бойових спроможностей системи озброєння тактичної авіації, динаміку зміни оперативного середовища та результати прогнозу економічної спроможності держави із ресурсного забезпечення розвитку системи озброєння авіації на 
всій глибині планування. Такі формалізовані критерії дозволяють здійснювати постановку математичної задачі синтезу раціональної програми оновлення системи озброєння тактичної авіації ПС ЗС України у зворотному вигляді, придатному для пошуку рішення відомими та апробованими математичними методами теорії оптимізації, що дає підстави вважати мету статті досягнутою.

Подальші дослідження планується спрямувати на побудову “дерева рішень” щодо формування програм розвитку системи озброєння авіації ПС ЗС
України на заданій глибині планування, що грунтуватиметься на виборі запропонованих критеріїв оцінювання програм на етапі їх синтезу в залежності від співвідношення наявних і необхідних спроможностей для виконання завдань за сценаріями застосування Повітряних Сил, економічної спроможності держави щодо ресурсного забезпечення реалізації заходів розвитку системи озброєння тактичної авіації, а також в залежності від прогнозу щодо зміни середовища безпеки.

\section{Список літератури}

1. Указ Президента України від 04.06.2016 року № 240/2016 “Про рішення Ради національної безпеки і оборони України від 20.05.2016 “Про Стратегічний оборонний бюлетень України”.

2. Указ Президента України від 26.05.2015 року № 287/2015 “Про рішення Ради національної безпеки і оборони України від 06.05.2015 “Про Стратегію національної безпеки України”.

3. Указ Президента України від 14.03.2016 року № 92/2016 "Про рішення Ради національної безпеки і оборони України від 04.03.2016 “Про Концепцію розвитку сектору безпеки і оборони України”.

4. Офіційний сайт Міністерства оборони України. Рекомендації з оборонного планування на основі спроможностей. - Режим доступу: https://www.mil.gov.ua/content/other/Recommendationson_CBP_120617.pdf.

5. Руснак І.С. Розвиток методологічних положень обгрунтування заходів організаційного будівництва (реформування) Повітряних Сил ЗС України / І.С. Руснак, О.М. Загорка // Наука і оборона. - 2010. - № 1. - С. 6-12.

6. Чепков І.Б. Основні аспекти методології формування та супроводження реалізації середньострокових програм озброєння в умовах особливого періоду / І.Б. Чепков, М.І. Луханін, І.В. Борохвостов // Озброєння та військова техніка. - 2016. - № 4(2). - С. 3-8.

7. Системная методология планирования развития, предпроектных исследований и внешнего проектирования вооружения и военной техники / Б.А. Демидов, М.И. Луханин, А.Ф. Величко, М.В. Науменко / Под ред. Б.А. Демидова. К.: “Стилос", 2011. - 464 с.

8. Оборонна реформа: системний підхід до оборонного менеджменту: монографія / А. Павліковський, В. Фролов, Ф. Саганюк та ін.; за заг. ред. А. Сиротенка. - Київ: НУОУ, 2020. - 274 с.

9. Оборонний огляд: український вимір 2014 -2018: монографія / Ф. Саганюк, А. Павліковський, П. Щипанський та ін.; за заг. ред. І. Руснака. - Київ: МО та ГШ ЗС України, НУОУ, 2019. - 196 с.

10. Сучасний метод бойових потенціалів в прикладних задачах планування розвитку та застосування тактичної авіації: монографія / Б.Й. Семон, О.Б. Леонтьєв та ін. - К.: НАОУ, 2009. - 336 с.

11. Котов О.Б. Обгрунтування вибору критеріїв раціональності кількісно-якісного складу повітряної компоненти міжвидового збройного угруповання / О.Б. Котов, І.С. Романченко // Збірник наукових праць ХУПС. - 2012. - № 3(9). C. 14-17.

12. Дроздов С.С. Методика постановки та розв'язування зворотної задачі оптимізації бойового (кількісно-якісного) складу тактичної авіації і зенітних ракетних військ перспективних Повітряних Сил / С.С. Дроздов, О.Б. Леонтьєв // Наука і техніка Повітряних Сил Збройних Сил України. - 2017. - № 2(27). - С. 7-14. https://doi.org/10.30748/nitps.2017.27.01.

13. Класифікація та оцінка впливу факторів під час формування програм та планів розвитку збройних сил / О.М. Семененко, О.Г. Водчиць, Ю.Б. Добровольський, Р.В. Бойко, О.А. Корочкін // Системи озброєння і військова техніка. - 2015. - № 2(42). - С. 183-187.

14. Методичний підхід щодо підвищення ефективності виконання заходів програм розвитку Збройних Сил України шляхом раціонального розподілу фінансових ресурсів на них / О.І. Кремешний, Р.В. Бойко, О.М. Семененко, І.М. Чернишова // Збірник наукових праць Харківського університету Повітряних Сил. - 2012. - № 2(31). - С. 19-23.

15. Формування порядку воєнно-економічного оцінювання результатів виконання заходів та програм розвитку Збройних Сил України / Р.В. Бойко, О.М. Семененко, О.І. Кремешний, I.М. Чернишова // Системи озброєння і військова техніка. - 2011. - № 3(27). - С. 98-101.

16. Метод оцінювання ефективності виконання програм (планів) розвитку Збройних Сил України з урахуванням повноти та своєчасності їх фінансування / О.М. Семененко, О.Г. Водчиць, Л.М. Семененко, Р.В. Бойко, Д.В. Башинський, Г.Г. Зубрицька //Збірник наукових праць Харківського національного університету Повітряних Сил. - 2017. № 2(51). - C. 51-58. https://doi.org/10.30748/zhups.2017.51.10.

17. Борохвостов І.В. Визначення критеріїв та методів оцінювання шляхів забезпечення військових формувань озброєнням та військовою технікою / І.В. Борохвостов, М.О. Білокур // Озброєння та військова техніка. - 2018. № 3(19). - С. 3-8.

18. Мунтіян В.І. Економічна безпека України / В.І. Мунтіян. - К.: КВІЦ, 1999. - 139 с.

19. Борохвостов І.В. Визначення теорії програм озброєння як наукового напряму теорії озброєння / І.В. Борохвостов // Озброєння та військова техніка. - 2017. - № 1(13). - С. 9-17. 
20. Бадрак В.В. Переозброєння Збройних Сил України: раціоналізація підходів, пошук альтернативних шляхів / В.В. Бадрак // Озброєння та військова техніка. - 2016. - № 1(9). - С. 3-8.

21. Леонтьєв О.Б. Напрями удосконалення науково-методичного апарату обгрунтування основних напрямів розвитку системи озброєння авіації Повітряних Сил Збройних Сил України / О.Б. Леонтьєв, М.В. Науменко // Наука і техніка Повітряних Сил Збройних Сил України. - 2020. - № 3(40). - С. 69-78. https://doi.org/10.30748/nitps.2020.40.08.

22. Закон України “Про національну безпеку України” від 21.06.2018 № 2469-VIII [Електронний ресурс]. - Режим доступу: https://zakon.rada.gov.ua/laws/show/2469-19\#Text.

23. Єдиний перелік (каталог) спроможностей Міністерства оборони України, Збройних Сил України та інших складових сил оборони (затвердж. Міністром оборони України від 09.12.2019 № 7983/в/36.). - К.: Міністерство оборони України. - 2019. - 618 с.

24. Візія Повітряних Сил 2035. - Вінниця: Командування Повітряних Сил Збройних Сил України. - 2020. - 42 с.

\section{Відомості про авторів:}

\section{Дроздов Сергій Семенович}

кандидат військових наук

Командувач Повітряних Сил

Збройних Сил України,

Вінниця, Україна

https://orcid.org/0000-0001-9704-4023

\section{Леонтьєв Олексій Борисович}

доктор технічних наук професор головний науковий співробітник

Харківського національного університету

Повітряних Сил ім. І. Кожедуба,

Харків, Україна

https://orcid.org/0000-0003-4003-7759

\section{Науменко Марина Володимирівна}

кандидат технічних наук старший науковий співробітник провідний науковий співробітник

Харківського національного університету

Повітряних Сил ім. І. Кожедуба,

Харків, Україна

https://orcid.org/0000-0002-1216-9263

\section{Information about the authors:}

\author{
Serhii Drozdov \\ Candidate of Military Sciences \\ Commander of the Air Force \\ of the Armed Forces of Ukraine, \\ Vinnytsia, Ukraine \\ https://orcid.org/0000-0001-9704-4023
}

\author{
Oleksii Leontiev \\ Doctor of Technical Sciences Professor \\ Chief Research \\ of Ivan Kozhedub Kharkiv \\ National Air Force University, \\ Kharkiv, Ukraine \\ https://orcid.org/0000-0003-4003-7759
}

Maryna Naumenko

Candidate of Technical Sciences Senior Research

Lead Research

of Ivan Kozhedub Kharkiv

National Air Force University,

Kharkiv, Ukraine

https://orcid.org/0000-0002-1216-9263

ФОРМАЛИЗОВАННЫЕ КРИТЕРИИ РАЦИОНАЛЬНОСТИ ПРОГРАММЫ РАЗВИТИЯ СИСТЕМЫ ВООРУЖЕНИЯ ТАКТИЧЕСКОЙ АВИАЦИИ ВОЗДУШНЫХ СИЛ ВООРУЖЕННЫХ СИЛ УКРАИНЫ НА ДОЛГОСРОЧНОЙ ПЕРСПЕКТИВЕ

С.С. Дроздов, А.Б. Леонтьев, М.В. Науменко

Рассмотрены основные возможные случаи нехватки боевой способности тактической авиации Воздушных Сил Вооруженных Сил Украины в начале долгосрочного периода планирования развития ее системы вооружения и связанные с ними возможные варианты выбора стратегий переоснащения авиачионных частей на новую боевую авиационную технику для ликвидации имеющегося недостатка. Названные варианты стратегий предлагается свести в три основные группы, а именно: стратегию устойчивого развития, когда необходимая способность достигается в конце периода планирования, стратегию постоянной ликвидации недостатка способности в течение всего периода планирования, и стратегию быстрой ликвидации недостатка способности за минимально возможное время. Предложены формализованные, с применением метода боевых потенциалов, критерии рациональности программы развития системы вооружения тактической авиации Воздушных Сил Вооруженных Сил Украины, посредством использования которых, в отличие от известных методических подходов, возможно осуществить синтез такой рациональной программы в обратной постановке математической задачи оптимизации.

Ключевые слова: планирование на основе возможностей, критерии рациональности, научно-методический аппарат, оптимизачия, рациональная программа развития, система вооружения тактической авиаџии Воздушных Сил Вооруженных Сил Украины. 


\title{
FORMALIZED CRITERIA FOR THE RATIONALITY OF THE PROGRAM FOR THE DEVELOPMENT OF THE WEAPONS SYSTEM OF TACTICAL AVIATION OF THE AIR FORCE OF THE ARMED FORCES OF UKRAINE IN THE LONG-TERM PERSPECTIVE (FORECASTED) THREAT
}

\author{
S. Drozdov, O. Leontyev, M. Naumenko
}

It has been determined that the current state of the fleet of tactical aviation combat aircraft of the Air Force of the Armed Forces of Ukraine needs urgent replacement with new multi-functional fighters. This necessitates substantiating the prospective quantitative and qualitative composition of the fleet of tactical aviation aircraft and solving the problem of synthesizing a rational program for updating this fleet, balanced with the economic capabilities of the state. Modern methodological approaches to solving the problem of synthesizing the program for the development of the armament system of the branches of the armed forces and combat arms, including tactical aviation, based on the scheme for generating alternative options with their subsequent assessment and choosing the best option according to the selected system of criteria. At the same time, the criteria for choosing the best option do not provide for the presence of formalized connection between the parameters of the weapons system development program, making it impossible to apply such criteria to formulate and solve mathematical optimization problems in the opposite form.

The article contains the main possible cases of shortage of the combat ability of tactical aviation of the Air Force at the beginning of the long-term planning period for the development of its weapons system and the associated possible options for choosing strategies for re-equipping aviation units with new military aviation equipment to eliminate the existing shortage.

These strategy options are proposed to be brought into three main groups: the strategy of sustainable development, when the ability is required to be achieved at the end of the planning period, the strategy of permanent elimination of the lack of capacity throughout the entire planning period, and the strategy of rapid elimination of the lack of capacity in the shortest possible time. Formalized, using the method of combat potentials, criteria for the rationality of the program for the development of the weapon system of tactical aviation of the Air Force, through the use of which, in contrast to the known methodological approaches, it is possible to synthesize such rational program in the reverse formulation of the mathematical optimization problem are proposed.

Keywords: planning on the basis of capabilities, criteria of rationality, scientific and methodological mechanism, optimization, rational development program, weapons system of tactical aviation of the Air Force of the Armed Forces of Ukraine. 